\title{
Lockout At American Crystal Sugar
}

\author{
Katherine Campbell, Ph.D., University of North Dakota, USA \\ Duane Helleloid, Ph.D., University of North Dakota, USA \\ Patrick Schultz, Ph.D., University of North Dakota, USA \\ John Vitton, Ph.D., University of North Dakota, USA
}

\begin{abstract}
As a June 23, 2012, vote neared, union workers at American Crystal Sugar were deciding whether the time had come for them to approve the contract offer by the company. Workers continued to staff picket lines at factory entrances, although enthusiasm for consistently staffing the picket line was waning (Lee 2012(1)). Replacement workers had operated the factories for nine months, successfully processing the 2011 sugar beet harvest. The company reported that although there had been some minor problems, all plants were running at nearly full capacity without the union workers. Company leaders indicated they were "attempting to adjust what they consider an archaic labor contract with newer standards that are competitive with other union rates" (Porter, 2012). The union had consistently been voting down the company's contract offers for almost a year. Workers stated they were standing firm to protect their jobs, salaries, benefits, and promotion opportunities, and were not willing to give away "rights" they had been fighting for the past 50 years (Kolpack, 2011). Yet, many union workers knew that their bargaining power had been significantly eroded by the company's ability to operate with non-union replacement workers.
\end{abstract}

Keywords: Labor Lockout; American Crystal Sugar; Stakeholder Analysis; Union Bargaining Power

\section{AMERICAN CRYSTAL SUGAR}

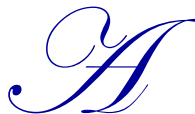
merican Crystal Sugar (hereafter referred to as the "company") was the largest sugar beet processor in the United States (processing 38\% of beet production), selling about $15 \%$ of all sugar sold in the country. Organized as a cooperative, it was owned by the 2800 farmers that raised approximately 420,000 acres of sugar beets. Total revenues for 2010 were over $\$ 1.4$ billion. The company itself, or through affiliates, operated plants in Minnesota, North Dakota, Iowa, and Montana, and marketed its products under the Crystal Sugar brand (ACS Annual Report, 2010). The climate in this area was well suited for growing sugar beets from May through September. During the winter months the ground was covered with snow, and temperatures generally fell below freezing for months.

Roots of the cooperative went back over 100 years, as local farmers banded together to invest in processing facilities that could refine sugar beets into sugar. The current cooperative, American Crystal Sugar, was the result of a number of different mergers, joint ventures, and divestitures over the past century (ACS Timeline, ACS Products and Processing). Shares of the cooperative were bought and sold among farmers, with one share essentially allowing a farmer to devote one acre of land to growing sugar beets. Depending on the yield (amount produced per acre), sugar content, and sugar prices, the cooperative might not process all the beets grown, with the remainder simply plowed under. The crop harvested in 2010 had proven to be one of the most lucrative ever for farmers, as American Crystal Sugar had been able to pay growers (shareholders) $\$ 73.02$ per gross ton. The previous record was in 1974 , with a payment of $\$ 57.14$ per ton (Pates, 2011).

\section{REFINING SUGAR BEETS}

The economies of scale in the production of sugar from beets required large processing facilities that were located close to farms, in order to decrease the cost of transporting raw beets. Once refined into sugar, a significant portion of the weight of the beets was removed, and transportation of the refined sugar to grocery distributors and 
food manufacturers nationwide was economical. In order to keep large companies from operating the processing facilities, and potentially capturing all the profits from sugar beet harvesting and processing, farmers had tended to form cooperatives to fund the building of sugar production facilities, and then return profits back to the farmers.

Sugar beet seeds were planted in the spring, with the harvest typically beginning in September. During September and October the beets were harvested, and transported to large storage facilities in proximity to either farms, or processing facilities. The processing facilities began operations in September and ran 24 hours per day, extracting and refining the sugar from the beets. Processing continued until the spring. It was important to complete the processing before warm weather began, or the beets would begin to rot and not be able to be processed. Hence, while sugar beet processing facilities needed to be fully staffed from September through May, during the summer many workers were furloughed, and worked on farms, or in the construction industry. (At American Crystal Sugar, most of these "seasonal" or " $\sim 9$ month" workers were members of the Bakery, Confectionery, Tobacco Workers and Grain Millers International Union, hereafter referred to as the "union.") Some managers and full-time workers continued working at the plant during the summer, performing scheduled maintenance and upgrades, and preparing the facility for the arrival of the next harvest.

\section{IMPORT QUOTA ON SUGAR}

Since the mid 1980s, the U.S. sugar market operated under a quota system whereby only about three billion pounds of sugar were allowed to be imported into the country annually. Any sugar imported in excess of this was subject to a tariff that made the price prohibitively expensive. Over the past thirty years the world price of sugar ranged between 5-13 cents per pound, whereas the price in the U.S. ranged between 20-24 cents per pound. In March 2010, world prices had risen to 19.67 cents per pound, and U.S. prices were 35.02 cents per pound (Galles, 2010). The quota system allowed sugar beet farmers to generally grow sugar beets without price supports or other forms of payments from the U.S. Department of Agriculture, whereas most other crops received some form or another of taxpayer support (whereas it was direct consumer support, through higher prices, in the case of sugar). In recent years as Congress debated farm bills, and farm support, sugar beet farmers argued that they did not need direct government subsidies (because they were already protected by the import quotas). Labor unions had generally joined with sugar companies and farmers to jointly lobby for continuation of the sugar import quota system.

The import quota, by raising the price of sugar in the U.S., affected more than simply the price of sugar in the grocery store. Every food item that contained sugar was marginally more expensive as a result, and some manufacturers had shifted to other sweeteners (e.g., high fructose corn syrup), which drove up the price of those sweeteners as well (and as a result, other corn-based products, including meats and ethanol). In addition, some manufacturers had shifted production elsewhere (e.g., Canada, Mexico) where sugar prices were lower, and then shipped the finished products (e.g., Life Savers, Red Hots, Jawbreakers) back to the U.S. without needing to pay tariffs or be subjected to quotas (Galles, 2010).

\section{THE LOCKOUT}

As production from the 2010 growing season was wrapping up in May 2011, contract talks between the company and the union had been underway for several months. The company was looking to negotiate a new five year contract that would provide a $17 \%$ raise, while also asking union employees to pay a portion of their health insurance costs. In addition, the company wanted to liberalize rules that restricted the use of contractors at the processing facilities, and eliminate rules that gave employees with seniority preference over other employees in promotions and extra work. Negotiations dragged on into the summer, with the two sides remaining far apart. Finally in July, American Crystal Sugar made a contract offer to its 1300 union employees, and indicated that they either needed to vote to approve the contract, or they would be locked out from plant. In this case, the company would start hiring replacement workers in order to begin training, and have the replacement workers prepared to operate the equipment by the time the plants would start up in September. Union members voted overwhelmingly (96\%) to reject the proposed contract, resulting in the company barring union members from work beginning August $1,2011$. 
The company indicated that it was surprised by the vote, but that it needed to move on and prepare for the upcoming harvest and processing season, and hire replacement workers. Company managers indicated that they were confident that they could train new employees, and "not miss a beat" once processing started. Union members were confident that they were not so easily replaceable: "The jobs we do, it's not rocket science, nor are we brain surgeons. But the jobs we do in the factories are very skillful jobs. I just don't believe they are going to be able to run five factories with transient workers who have never been in a sugar factory" (Kolpack, 2011).

\section{THE "FINAL" CONTRACT OFFER}

As the processing facilities began full operation, the company reported that they were running at near capacity, and that there had been only a few disruptions. In October 2011, the company proposed a contract that would allow union workers to return to work, and gave the union until November $1^{\text {st }}$ to approve the contract. The new offer gave greater assurances that contractors would not be used to replace union workers, but on some other matters was less favorable than the contract offer that had been rejected in July. (Appendix 1 provides a summary of the union, and company positions, on the contract offer.) The union voted overwhelmingly to reject the offer, with $90 \%$ of members voting against it. "Today our members sent a loud and clear message to American Crystal executives .... We want to work, but we will not accept a contract that puts our jobs and the entire community at risk." (Lee, 2011)

Replacement workers continued to operate the factories throughout the winter, processing sugar beets consistent with a typical schedule. The company indicated that it had hired about 800 "local" replacement workers, from a pool of 7000 applicants (Bakken 2012). Some of these replacement workers were former union members who gave up their union membership (and seniority) in order to return to work (Bakken 2012). Additional workers were provided by an employment services firm on a temporary basis (Pates, 2012). In May and June the replacement workers were let go for the summer, and the factories were shut down for their regular repair and maintenance.

Although negotiations had taken place sporadically since the November vote, and various politicians had intervened to try and bring the two sides together, the company maintained that its October proposal was the final contract offer, and that the union could either accept it, or they would continue to be locked out. The company had run ads in local papers for "permanent" replacement workers, although the full details of their employment contracts were not made public. The union had indicated that it would lobby against continuation of the existing sugar program, saying they would "do what we can to educate the urban legislators that are friendly to labor and tell them what Crystal Sugar is doing to the working class and the labor people" (Lee 2012(2)). The union scheduled a vote for June 23, 2012, to allow members to again vote on whether they wanted to return to work in September under the terms outlined by the company in their "final" offer.

\section{DISCUSSION QUESTIONS}

1. What factors may have influenced American Crystal Sugar's decision to revise its contract with the union, and risk the potential of a lockout or strike?

2. Why were union members so overwhelmingly opposed to the contract proposal American Crystal Sugar presented in July 2011 ?

3. Between August 2011 and June 2012, how did the bargaining power of American Crystal Sugar change? How did the bargaining power of the union change?

4. Besides the union and the company, what other stakeholders have the potential to influence the outcome of negotiations over a new contract? What other stakeholders should the company be using to influence the outcome? What other stakeholders should the union use to influence the outcome?

5. If asked by a union member, what recommendation would you give them regarding the upcoming vote on the contract?

6. Is the union's statement that it will lobby against continuation of the sugar quota system a credible threat? 


\section{AUTHORS INFORMATION}

Katherine Campbell is a Professor of Accountancy at the University of North Dakota. E-mail: kcampbell@business.und.edu

Duane Helleloid is a Professor of Management, and former department chair, at the University of North Dakota. E-mail: duane.helleloid@und.edu (Corresponding author)

Patrick Schultz is an Associate Professor Management at the University of North Dakota. E-mail: Patrick.schultz@und.edu

John Vitton is an Associate Professor of Management, and former department chair, at the University of North Dakota. E-mail: John.vitton@und.edu

\section{REFERENCES}

1. ACS Timeline. Retrieved from: http://www.crystalsugar.com/coopprofile/history.aspx

2. ACS Products and Processing. Retrieved from: http://www.crystalsugar.com/coopprofile/history.aspx

3. American Crystal Sugar Annual Report 2010.

4. $\quad$ Bakken, Ryan 2012. Crystal: Final offer. Grand Forks Herald, May 4, 2012, page A1.

5. Eccher, Marino 2011. Breaking down the breakdown: Where Crystal, union differ on contract issues. Grand Forks Herald, November 3, 2011, page A1.

6. Galles, Gary M. 2010. End the import quotas on sugar. St. Petersburg Times, March 23, 2010.

7. Kolpack, Dave. 1,300 workers locked out at American Crystal Sugar. Associated Press, August 1, 2011.

8. Lee, Stephan 2011. Union workers reject contract. Grand Forks Herald, November 2, 2011, page A1.

9. Lee, Stephan 2012(1). More talks, no settlement. Grand Forks Herald, February 1, 2012, page A1.

10. Lee, Stephan 2012(2). Union will fight sugar program. Grand Forks Herald, February 2, 2012, page A1.

11. Pates, Mikkel 2011. Crystal offers record beet payments. Agweek, November 8, 2011, page 1.

12. Pates, Mikkel 2012. Crystal: Union's lockout estimate too high. Grand Forks Herald, April 27, 2012, page 1.

13. Porter, Caroline 2012. Midwest Sugar-Beet Workers Hold Contract Vote. Wall Street Journal, June 23, 2012, page A2-A3. 


\section{APPENDIX 1}

(This appendix is a significantly abbreviated version of information presented in Eccher (2011))

\section{Health care costs}

- $\quad$ Under the old contract: Union workers paid no premiums.

- $\quad$ The company's position: Employees would pay 17 percent of health care premiums while the company would pay 83 percent, the same allocation of expenses as non-union employees and managers currently pay.

- The union's position: The union wants to retain the existing plan on premiums, with possible concessions on drug costs and the use of generic drugs.

\section{Subcontracting rules}

- Under the old contract: Except in emergencies, the company had to give the union 15 days' notice before awarding a nonunion subcontract, and 10 days to discuss the proposal.

- The company's position: The company wants change it to five days, and two days, respectively. It has specified that union members would not lose their jobs due to subcontracting, and clarified when subcontracting is allowed.

- The union's position: The union accepts the shortened time frame, but has concerns over increased use of non-union subcontractors.

\section{Year-round employee status}

- Under the old contract: Employees are eligible for year-round status (and benefits) if they work $75 \%$ of the scheduled work days in a year.

- $\quad$ The company's position: The company wants to raise it to $85 \%$, and add a skills test to make sure those employees are qualified for mechanical and plant work as well as processing.

- $\quad$ The union position: The union wants to keep the threshold closer to 75 , concerned that many workers would lose benefits with a higher threshold.

\section{Rules for hiring}

- Under the old contract: Seniority was generally the deciding factor when determining who would fill a position, as long as they met the minimum qualifications.

- $\quad$ The company's position: The company wants to be able to hire the most qualified individuals, including new hires, to fill open positions. Seniority would only be relevant in a tie-breaker situation.

- $\quad$ The union's position: The union wants to retain the seniority-based system.

\section{Overtime}

- Under the old contract: Overtime opportunities were allocated based on seniority, and sick leave and paid vacation time counted toward seniority.

- The company's position: The company wants to include other factors when assigning overtime (e.g., skills, work-group cohesiveness), and count only "actual hours worked" towards seniority.

- The union's position: The union wants to retain the current emphasis on seniority, and the way time is calculated.

\section{Retention of seniority}

- Under the old contract: Employees who took a leave retained seniority and were generally guaranteed a job on return. 
- $\quad$ The company's position: The company wants seniority to be forfeited if an employee takes a long leave (whether medical or personal).

- The union's position: The union wants to retain the existing seniority and leave system. 